\title{
The Construction of Course Teaching Quality Monitoring System in Higher Vocational Colleges
}

\author{
Hongna Gao ${ }^{\mathrm{a}}$, Xiurong Wu ${ }^{\mathrm{b}}$, Yonghua Xuanc, Yinghua Qi ${ }^{\mathrm{d}}$, Guangyan Liu \\ Binzhou Polytechnic, Binzhou, China \\ aemail:ghn722976@126.com, ${ }^{b}$ email:13581168516@126.com,, bzxyh1969@126.com \\ d597611302@qq.com, email: 86562811@qq.com
}

Keywords: higher vocational colleges; teaching quality; monitoring system; construction

\begin{abstract}
The development of socialist market economy puts forward higher requirements for the quality of talents. As the important place to provide talents to the society, higher vocational colleges shall establish scientific and reasonable teaching quality monitoring system and improve their competitiveness. The construction of teaching quality monitoring system can correct problems existing in teaching management in time, which is conductive to the cultivation of high-quality talents.
\end{abstract}

\section{Introduction}

In higher vocational colleges, the construction of teaching quality monitoring system is the key part of teaching management, which can supervise the operation of teaching, promote the high-quality accomplishment of teaching objectives, and enhance students' learning efficiency ${ }^{[1]}$. The construction of course teaching quality monitoring system has become the advantage for higher vocational colleges to participate fierce competition. This paper, based on problems existing in teaching quality monitoring system, discusses the construction of the system.

\section{The Significance of the Construction of Monitoring System}

\subsection{To improve students' competitiveness in society}

In recent years, the popularity of higher vocational colleges drives them to increase enrollment. Therefore, when the number of students is increasing, how to improve their competitiveness has become the problem to be focused on. The aim of higher vocational colleges is to cultivate high-competence skilled talents, strengthening "specialized education”. Students' vocational skills and professional degree play a significant role in the training of core competitiveness. The construction of course teaching quality monitoring system in higher vocational colleges can supervise teaching plan to customize teaching according to situations of students and provide system guarantee for them, and give full play to the teaching creativity of teachers and personalized advantages of students to make them excel in skills. Therefore, the construction of the system is able to improve the quality of students and help students to exert their advantages in society and improve their competitiveness.

\subsection{To orderly carry out management work}

The construction of course teaching quality management monitoring system in higher vocational colleges can collect information of teaching management, which, after processing and analysis, can reflect a series of problems existing in teaching management. For instance, teaching objective plays an importantly guiding role in teaching process, however, the teaching quality monitoring system can monitor whether there is deviation from teaching objectives in teaching process, so as to promote the accomplishment of teaching objective. Take ideological and political course in higher vocational colleges as an example, shown in Table 1. 
Table 1 Take ideological and political course in higher vocational colleges as an example.

\begin{tabular}{|c|c|c|}
\hline \multirow{12}{*}{ Teaching Objectives } & \multirow{5}{*}{ Theoretical Guidance } & 1. Marxist hominology theory \\
\hline & & $\begin{array}{l}\text { 2. Mao Zedong Thought and the theoretical } \\
\text { system of socialism with Chinese } \\
\text { characteristics }\end{array}$ \\
\hline & & $\begin{array}{l}\text { 3. Ideological and moral cultivation and basic } \\
\text { law education }\end{array}$ \\
\hline & & $\begin{array}{l}\text { 4. Situation and Policy, and the Important } \\
\text { Thought of Three Represents }\end{array}$ \\
\hline & & $\begin{array}{l}\text { 5. Overview of Mao Zedong Thought and the } \\
\text { theoretical system of socialism with Chinese } \\
\text { characteristics }\end{array}$ \\
\hline & \multirow{3}{*}{$\begin{array}{c}\text { Objectives of Process and } \\
\text { Method }\end{array}$} & $\begin{array}{l}\text { 1. Education on world outlook, outlook on life } \\
\text { and values. To fully recognize great changes } \\
\text { in China's economic society. }\end{array}$ \\
\hline & & $\begin{array}{l}\text { 2.To analyze and grasp human from social } \\
\text { nature of human. To clearly know basic } \\
\text { problems of life values from subjectivity, } \\
\text { historicality and development. }\end{array}$ \\
\hline & & $\begin{array}{l}\text { 3. To keep touch with facts and students in } \\
\text { method. To respect, understand and care for } \\
\text { students, being student-oriented. }\end{array}$ \\
\hline & \multirow{3}{*}{$\begin{array}{l}\text { Emotion, Attitude, and } \\
\text { Values }\end{array}$} & $\begin{array}{l}\text { 1.To cultivate students' habit of thinking and } \\
\text { capability of thinking. }\end{array}$ \\
\hline & & $\begin{array}{l}\text { 2.To cultivate civic awareness of students of } \\
\text { higher vocational colleges. }\end{array}$ \\
\hline & & $\begin{array}{l}\text { 3.To observe carefully, think diligently in } \\
\text { learning, and analyze and think realistically } \\
\text { according to theory and reality. }\end{array}$ \\
\hline & $\begin{array}{l}\text { Teaching Key Points and } \\
\text { Difficult Points }\end{array}$ & $\begin{array}{l}\text { To inherent ideological and political } \\
\text { education, and promote the vocational spirit. }\end{array}$ \\
\hline
\end{tabular}

\subsection{To enhance the popularity of colleges}

With the in-depth development of educational reform and changes of social concept, parents and students gradually have a more rational attitude towards higher vocational colleges. As a part of higher education in China, higher vocational college is the main place to cultivate vocational talents ${ }^{[2]}$. After senior school, with the help of parents, there are more choices for students, and higher vocational colleges are preferred by students and parents. In the trend, the competition between higher vocational colleges is fiercer, so teaching level and teaching quality of higher vocational colleges has become main reference standard for students to choose colleges. Scientific and effective course quality monitoring system has a significance for improving teaching quality and management, therefore, the construction of the system can enhance competitiveness of higher vocational colleges and improve the popularity of colleges.

\section{Problems in Current Monitoring System}

\subsection{Insufficient supervisors and competence}

The teaching quality monitoring system in higher vocational colleges is basically responsible by school-level steering committee, where supervisors are composed of old retired teachers. Retired teachers have the experience of supervising course teaching quality, which also probably hinders the management. With the scale expansion and increasing enrollment of higher vocational colleges, the requirements for teaching quality monitoring from colleges are also higher. Due to the constraint of ideological concept and knowledge structure, the guidance for supervisor is limited, and it is difficult to find and solve problems fundamentally, which results in the lack of guidance in teaching quality monitoring.

\subsection{Deviation in the evaluation of teaching quality}

In higher vocational colleges, traditional evaluation method is adopted in teaching evaluation, which pays more attention to the form and easily ignores other educational factors, thus causing 
one-sided evaluation results. Supervisor in teaching quality evaluation shall clearly understand the evaluation process so as to find out problems and provide guidance in teaching course. However, traditional evaluation, which emphasized the result and overlooked the process, easily ignores the evaluation process, which further limits teaching quality monitoring system of higher vocational colleges from exerting the significance.

\section{Measures to Construct the Monitoring System}

\subsection{To improve information mechanism and feedback channel of teaching information in higher vocational colleges}

In order to establish course teaching quality monitoring system of higher vocational colleges, the perfect collection of information in feedback system is the basis. The feedback of teaching information is one of easiest ways to find out problems in teaching. The information feedback system of higher vocational colleges can expand the scope of feedback personnel, requiring not only the participation of supervisor, but also the increasing proportion of student information feedback, which can promote teachers in higher vocational colleges to find out and solve problems more rapidly ${ }^{[3]}$. In addition, for information mechanism, a more strict system shall be formed to collect information from various aspects to ensure the accuracy and comprehensiveness of information and lay a foundation for better decision-making. Information mechanism and feedback channel of teaching information in higher vocational colleges shall be constructed and improved to give full play to the teaching quality monitoring system. Table 2 shows traditional feedback channel of teaching information, mainly adopting investigation method of paper table.

Table 2 Traditional feedback channel of teaching information, mainly adopting investigation method of paper table.

\begin{tabular}{|c|c|c|c|c|}
\hline Department & $\begin{array}{l}\text { Machinery and } \\
\text { Electrical } \\
\text { Department }\end{array}$ & Class & Filling Date & \\
\hline \multicolumn{5}{|c|}{$\begin{array}{l}\text { Welcome your comments and suggestions on teaching and teaching management such as teaching plan, content, method and } \\
\text { means, management and conditions (like classroom, laboratory etc.), evaluation and teaching staff of college (department), and } \\
\text { leaning status of students such as lesson, experiment, internship, assignment, examination and social practice. } \\
\text { We will seriously consider your suggestions and adjust the work to perform better teaching and teaching management. } \\
\text { Please hand over the feedback table to teaching information center, and your personal information will be strictly confidential. }\end{array}$} \\
\hline $\begin{array}{l}\text { Situation } \\
\text { Reflection and } \\
\text { Suggestion }\end{array}$ & \multicolumn{4}{|c|}{$\begin{array}{l}\text { I Teaching reform is mainly to read textbooks or courseware, lacking vitality. Course teachers of the class } \\
\text { have good attitude. The teaching is easily understood, except the teaching of abstract professional class. } \\
\text { Homework correction basically goes through the motions, however, question answering is not bad. } \\
\text { II The course arrangement is clear and reasonable, and teachers mentor students in classroom sometimes. } \\
\text { A large number of teachers are not strict with students, and the strictest teacher is teacher of professional } \\
\text { course. } \\
\text { III Students are always late for class, which is serious, and class discipline is sometimes good and } \\
\text { sometimes bad, including sleeping, chatting and playing the phone. The learning status of students in } \\
\text { classroom depends on the teaching competence of teachers. Students are active in extracurricular reading, } \\
\text { there is copying in homework, so the learning initiative is insufficient. }\end{array}$} \\
\hline $\begin{array}{l}\text { Measures and } \\
\text { Suggestion }\end{array}$ & \multicolumn{4}{|c|}{$\begin{array}{l}\text { It is suggested that teachers management students strictly, and the student union check the class } \\
\text { attendance in time, avoiding class skipping. Besides, students sleep so late that they get up late and be late } \\
\text { for class in the morning. There are too many meetings organized by teachers and student cadre, so it is } \\
\text { suggested to reduce the times of meeting to save time of students. }\end{array}$} \\
\hline $\begin{array}{l}\text { Contact } \\
\text { Information: }\end{array}$ & \multicolumn{4}{|c|}{ Year Month Date } \\
\hline
\end{tabular}

\subsection{To construct perfect incentive mechanism of teaching achievements}

In the construction, it is necessary to focus on strategies of management, establish better incentive mechanism and improve teaching enthusiasm of teachers ${ }^{[4]}$. Among course teachers in higher vocational colleges, some are young teachers in first employment after graduation. For them, training mechanism can be built to award teachers with better performance to promote the teaching level of young teachers. Besides, incentive mechanism can be established to unify teaching staff to perform their duties and responsibilities well, improve work quality, fully mobilize initiative of 
teaching staff and inspire their work enthusiasm.

\subsection{To appropriately deal with the relationship between supervisor expert and course teacher}

Supervisor expert shall respect course teachers and implement work with an equal attitude. In order to know the work of course teacher, supervisor expert needs to deeply understand the work of teachers in higher vocational colleges, face a series of problems in teaching with teachers, conduct in-depth discussion, and put forward reasonable solutions. Moreover, supervisor expert shall make clear of their duties and responsibilities, guide course teachers and promote them to grow more rapidly so as to provide more high-quality course content for students in higher vocational colleges ${ }^{[5]}$. In short, supervisor expert and course teachers are required to cooperate each other, establish equal cooperation relationship, and seek the future occupational development of students together.

\subsection{To guarantee the continuous improvement of course teaching quality monitoring system}

There are some problems in course teaching quality monitoring system in higher vocational colleges to be improved and perfected within a certain period of time. In the construction of the system, it is necessary to clear their school-running orientation and determine talent cultivation goal ${ }^{[6]}$. Higher vocational colleges shall not follow the crowd blindly, copy other colleges deliberately and cause bad competition, but improve themselves based on their orientation and goal. The construction of course teaching quality monitoring system in higher vocational colleges shall be a long-term mechanism ${ }^{[7]}$, and in the construction, higher vocational colleges shall uphold the people-oriented concept, put students' future in the first place, incessantly improve the monitoring system and provide high-quality talents for the society.

\section{Conclusion}

The construction of course teaching quality monitoring system in higher vocational colleges is a systematic project in teaching management, and the construction of scientific and long-term mechanism is an important part in the development of students and colleges. As the place to cultivate professional talents, higher vocational colleges are required to shoulder the responsibility to provide occupational talents for the country and society. Reasonable and effective course teaching quality monitoring system can put teaching objectives into practice, give full play to the teaching concept of higher vocational colleges, enhance the popularity, help students learn their advantages and train core competitiveness in social competition. In a word, the construction of teaching quality monitoring in higher vocational colleges is greatly important, and higher vocational colleges are required to make out reasonable planning according to their conditions.

\section{Acknowledgement}

Fund Program: University Science and Technology Program of Shandong Province (Project No. J18RB177)

Project name: Exploration and practice of effective ways and operation system of emergency rescue training

\section{References}

[1] Li Bangying. Exploration on Teaching Quality Monitoring Mechanism in Higher Medical Colleges [J]. Medical Journal of Chinese People’s Health, 2008, (23):2819.

[2] Wang Jin. Study on the Innovation and Reform of the Teaching Administration in the Higher Vocational Schools [D] Soochow University, 2010.

[3] Song Baorui. Research and Design of Classroom Teaching Quality Management Information System in Higher Vocational Colleges [D]. North China Electric Power University, 2012. 
[4] Zhang Bo. Research on Application of Decision-tree and Association Analysis in the Education Management of Higher Vocational Colleges [D]. Anhui University, 2013.

[5] Tang Wei. Research on Problems and Strategies of Teaching Management Staff in Higher Vocational Colleges [J]. Journal of Hubei University of Science and Technology, 2013.

[6] Tang Keping, Xu Fangheng. Problems and Measures of Teaching Management in Higher Vocational Colleges [J]. Adult Education, 2013.

[7] Tian Ye. Research on the Reform of Teaching Management of Higher Vocational Education under the Background of E-era [D]. Hebei University, 2015. 